\begin{tabular}{|c|c|c|}
\hline \multirow[t]{2}{*}{7} & $\begin{array}{l}\text { International Journal of Current Research in } \\
\text { Biosciences and Plant Biology }\end{array}$ & \\
\hline & Volume $4 \bullet$ Number 8 (August-2017) • ISSN: 2349-8080 (Online) & \\
\hline $\begin{array}{l}\text { EXCELLENT } \\
\text { PUBLISHERS } \\
\end{array}$ & Journal homepage: www.ijcrbp.com & wwwijecrip ocom \\
\hline
\end{tabular}

\title{
Leaf Anatomical Studies of Ziziphus mauritiana Lam.
}

\author{
M. P. Sivasankari ${ }^{1}$ and A. Sankaravadivoo ${ }^{2}$ \\ ${ }^{I}$ Assistant Professor, Department of Botany, Sri Meenakshi Government Arts College for Women, Madurai- 625 002, \\ Tamil Nadu, India \\ ${ }^{2}$ Assistant Professor, PG and Research Department of Botany, Government Arts College, Coimbatore- 641018 , \\ Tamil Nadu, India
}

*Corresponding author.

\section{Abstract}

The present investigation has been carried out to determine the leaf anatomical features of Ziziphus mauritiana belonging to the family Rhamnaceae. This plant is used for the treatment of different diseases and ailments of human beings. Its leaves, in particular are useful in the treatment of liver diseases, wounds, swelling and fever. Z. mauritiana shows midrib containing collateral vascular bundles. The lamina possesses reticulate venation with vein islets and well defined short and thick vein terminations. Calcium oxalate crystals are abundantly distributed both in leaf and leaf lamina. The internal structure shows that the cortex was represented with outer zone of collenchyma cells and inner zone of thin walled compactly arranged parenchyma cells. The petiole contains tannin and some cells are dilated with mucilage containing idioblast.

\section{Article Info}

Accepted: 22 July 2017

Available Online: 06 August 2017

Keywords

Calcium oxalate crystals

Leaf anatomy

Tannin

Ziziphus mauritiana

\section{Introduction}

Ziziphus is a multipurpose tree widely used in folklore medicine belonging to Rhamnaceae family. There are about 50 species in tropical Asia, Africa and America (Townsend and Guest, 1980). Among this, Ziziphus mauritiana commonly known as Indian ber is mostly found in all parts of India. Ziziphus mauritiana Lam. is a low branched deciduous tree with spreading crown, dark greenish black bark having irregular crack and strong reddish hardwood with oblong and elliptic leaves. The leaves are applied as poultices and are helpful in treating liver problems, asthma and fever and to cure sores (Michel, 2002). All parts of this are effective against different types of diseases. Also its leaves are useful in the treatment of diarrhea, wounds, abscesses, swelling and gonorrhea and are reported to have antioxidant activity (Morton, 1987; Dahiru and Obidoa, 2007). The leaf extract of this plant is known to possess anti ulcer activity (Ganachari and Shiv, 2004), antimicrobial activity (Sivasankari and Sankaravadivoo, 2015) and antibacterial activity (Chowdary and Padashetty, 2000).

Anatomical studies have much significance in different sectors of investigation. This study was aimed to provide valuable anatomical descriptions of Ziziphus mauritiana. Anatomically, studies on leaves provide a reliable additional evidence for the taxonomic delimitation. Since the anatomy of this genus is limited, the present study has been carried out to explore the anatomical features of leaf of Ziziphus mauritiana. 


\section{Materials and methods}

Fresh leaves of $Z$. mauritiana were collected from Muhavoor, near Rajapalayam and the plant was identified and authenticated by Botanical survey of India, Southern Regional centre, Coimbatore. The samples were cut and removed from the plant and they were washed in running water to remove dirt and soil.

It was then fixed in FAA (formalin - $5 \mathrm{ml}$, acetic acid $5 \mathrm{ml}$ and $70 \%$ ethyl alcohol $-90 \mathrm{ml}$ ) for 24 hours. After fixation, they were washed thoroughly in distilled water, dehydrated and embedded in paraffin wax. Then the paraffin wax embedded specimens were sectioned using rotary microtome. De-waxing was done by customary procedure (Johansen, 1940). The sections were stained with toluidine blue as per the method published by O'Brien et al. (1964). Where ever necessary, certain sections were also stained with safranin and fast green. Photographs of different magnifications were taken using Nikon digital camera 12 mega pixel and for normal observations, bright field was used. Descriptive terms of the anatomical features are as given in the standard anatomy books (Esau, 1964).

\section{Results and discussion}

Ziziphus mauritiana is a small to medium sized spiny shrub or tree with spreading crown growing up to the height of $12 \mathrm{~m}$ tall. The leaves are simple shining green above and whitish tomentose hairs beneath with minutely serrulate margins. The leaves are alternate, ovate or oblong, elliptic with rounded apex with longitudinal vein at the base. The leaves are solitary or in pairs and are about 2.5 to $3.5 \mathrm{~cm}$ long and 1.8 to 3.8 cm wide (Fig. 1)

Structural analysis is an important first step in the study and organization and changes in the plant body and it is externally useful in the study of plant morphogenesis (Wetmore and Wardlaw, 1951).

The leaves of Z. mauritiana contain 13 to $17 \%$ crude protein, $2 \%$ tannin and $15 \%$ fibre with tremendous medicinal properties (Hocking, 1993). They also contain alkaloids, protopine and berberine. In addition, it also possesses immune stimulant and cardiovascular properties (Morton, 1987). The anatomical studies on the leaves of Z. mauritiana Lam. can assist as relevant source of information and contribute towards identity of this plant in future exploration.

\section{Anatomy of Ziziphus mauritiana leaf}

The transverse section of the leaves possess a thick midrib which appears as though hanging from the abaxial side of the leaf. In Z. mauritiana, the abaxial leaf surface was glabrous, with comparatively few sunken stomata. The transverse section of the leaves revealed that it consists of epidermis, sub epidermis, vascular tissue and a large number of parenchyma cells around the vascular bundles (Fig.2). The vascular bundles arranged in a succession were open to the adaxial side of the epidermis. The lamina is smooth on the adaxial side and has a prominent ridge on the abaxial side. The midrib appears as plano convex with flat adaxial side with $650 \mu \mathrm{m}$ wide and $650 \mu \mathrm{m}$ thick.

The epidermal layer of the midrib is thin and wavy having small barrel shaped epidermal cells with prominent cuticle. The ground tissue consists of outer zone of 3 or 4 layers of collenchyma cells and inner zone of polyhedral, thin walled, compactly arranged parenchyma cells. Distributed in the ground tissue are seen fairly large mucilage secreting cavities. Although mucilage in the leaf lamina of Ziziphus was intracellular, the cortical and peripheral parenchyma of the major leaf veins contained significant amounts of extracellular mucilage.

Reports stated by Clifford et al. (2002) showed that the leaf veins had mucilage-filled spaces between the large-thin-walled outer collenchymatous cortical cells. Large amounts of intracellular mucilage were present in the leaf lamina of Ziziphus, with extracellular mucilages in the main leaf veins. Biochemical analysis of the water-soluble polysaccharides extracted together with the mucilage using enzymatic hydrolysis indicated that a water-soluble glucan may be present in the mucilage extract. The main role of the glucan, together with foliar starch, may be regarded as significant sources of monosaccharide sugars contributing to osmotic adjustment and remobilization of solutes to other organs as drought intensified.

The vascular strand is single, broadly cup shaped with collaterally arranged bundles with band of xylem and arc of phloem. The xylem elements are wide, angular, thick walled and arranged compactly in 2 to 6 celled parallel lines. Phloem consists of narrow, thick walled sieve elements and phloem parenchyma cells filled with dense tannin content. 


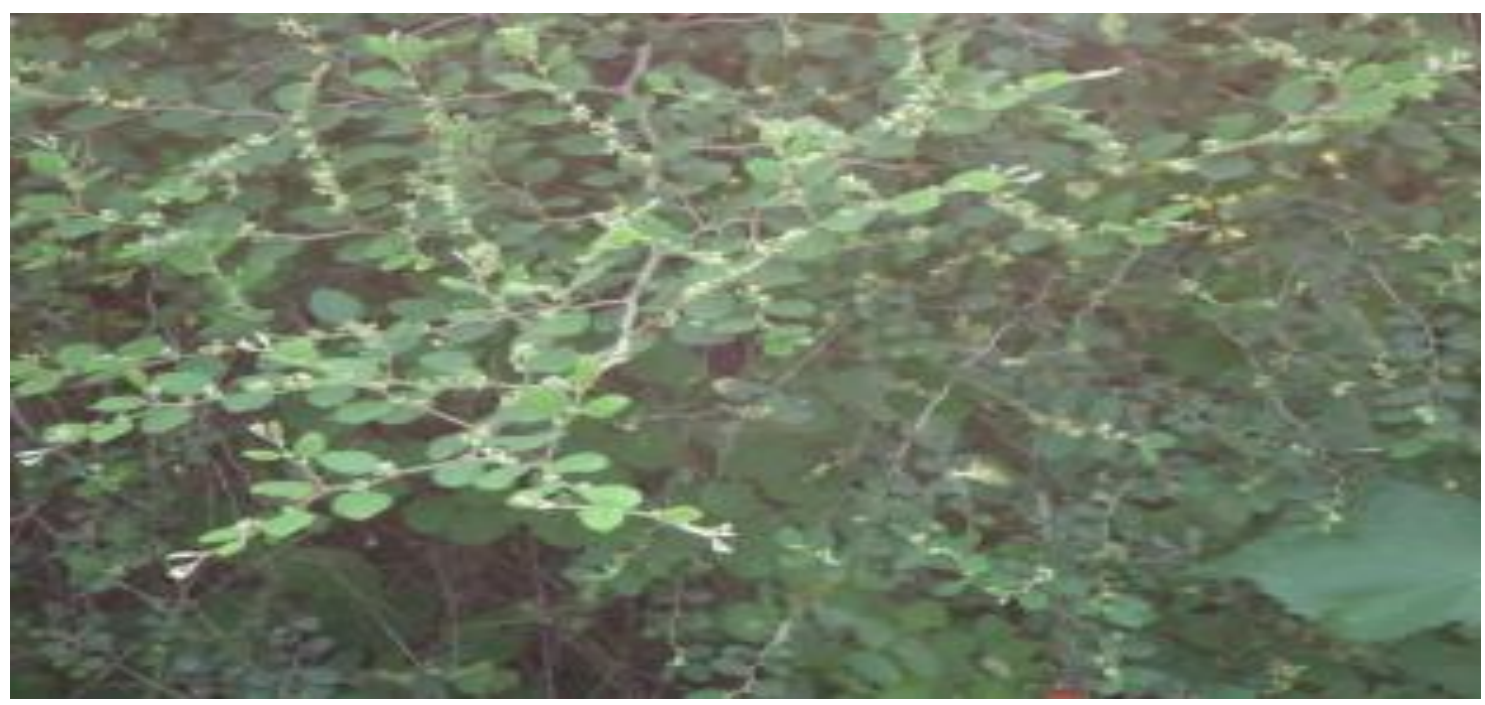

Fig. 1: Ziziphus mauritiana - habit.

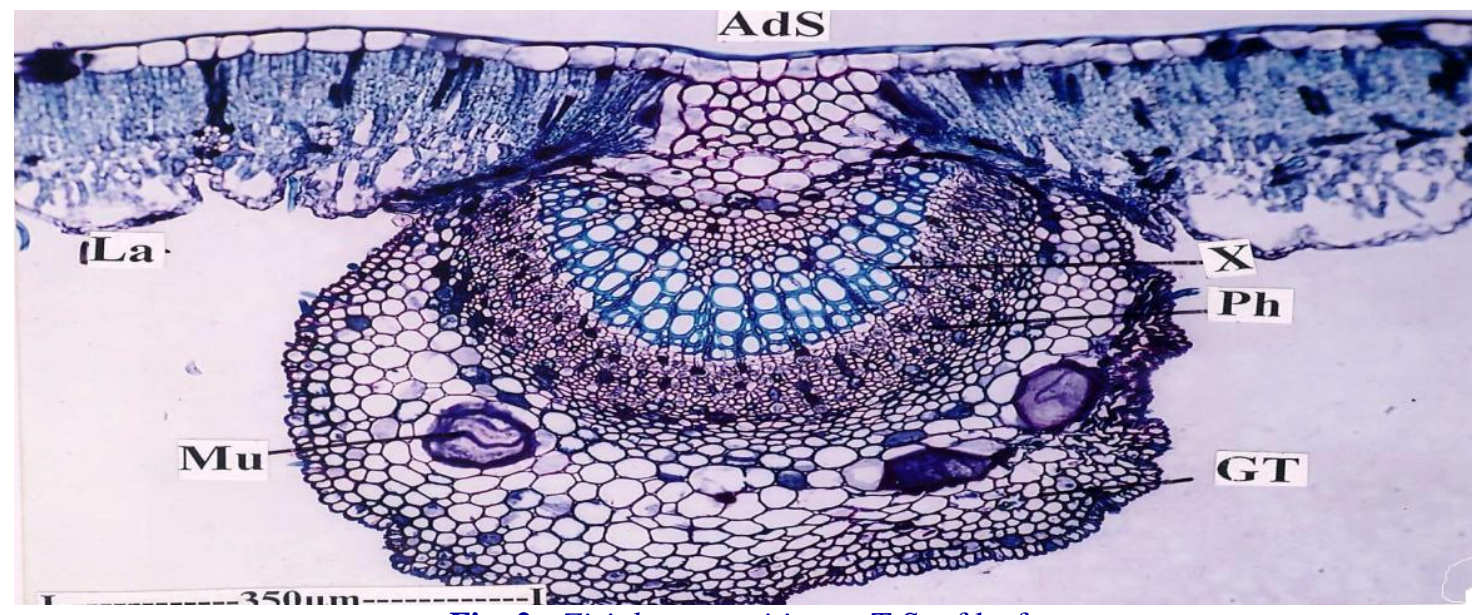

Fig. 2: Ziziphus mauritiana - T.S. of leaf.

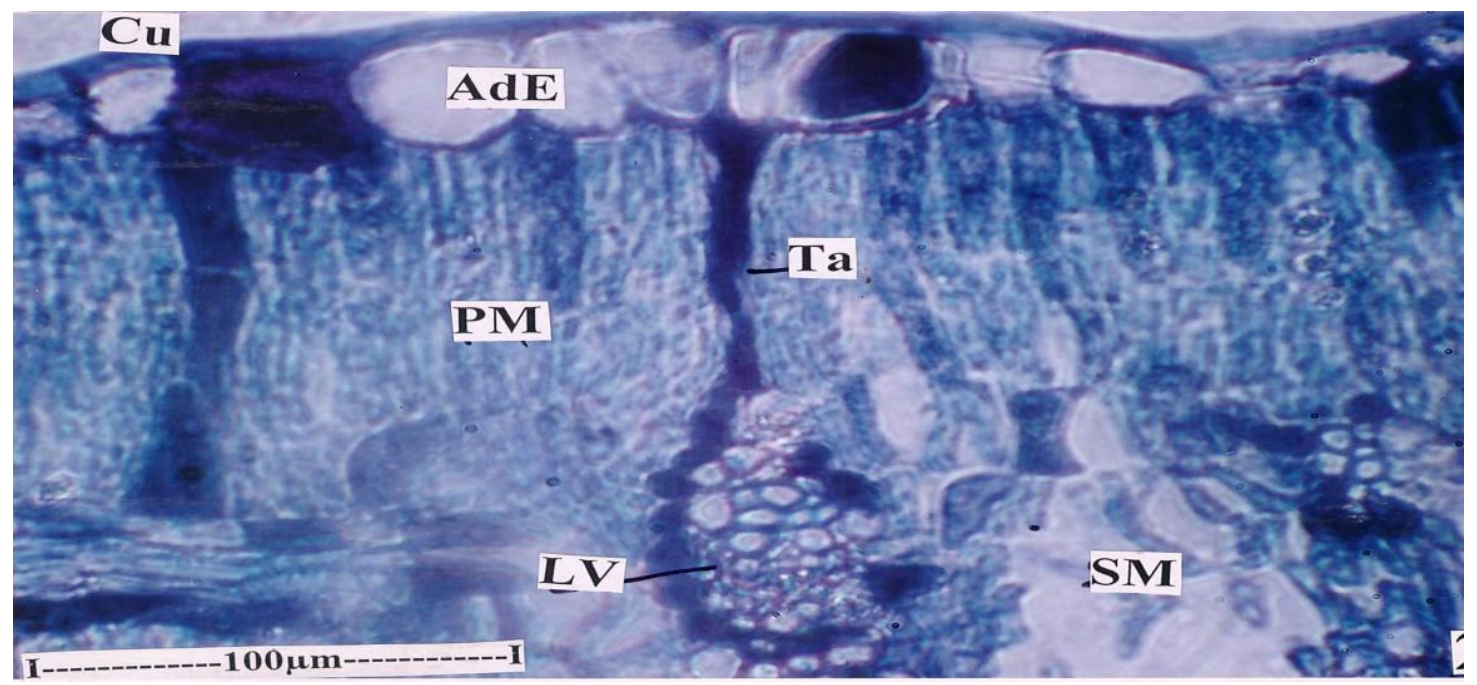

Fig. 3: Ziziphus mauritiana - T.S.of leaf lamina showing tannin deposition.

(Note: ADS-adaxial side, La-lamina, G.T- Ground tissue, Mu-mucilage, X -Xylem, Ph-Phloem, Mu- Mucilage, ADE-Adaxial epidermal, $\mathrm{Cu}$ - Cuticle, LV-Lateral vein, PM-Palisade mesophyll, SM-Spongy mesophyll, Ta-Tannin) 


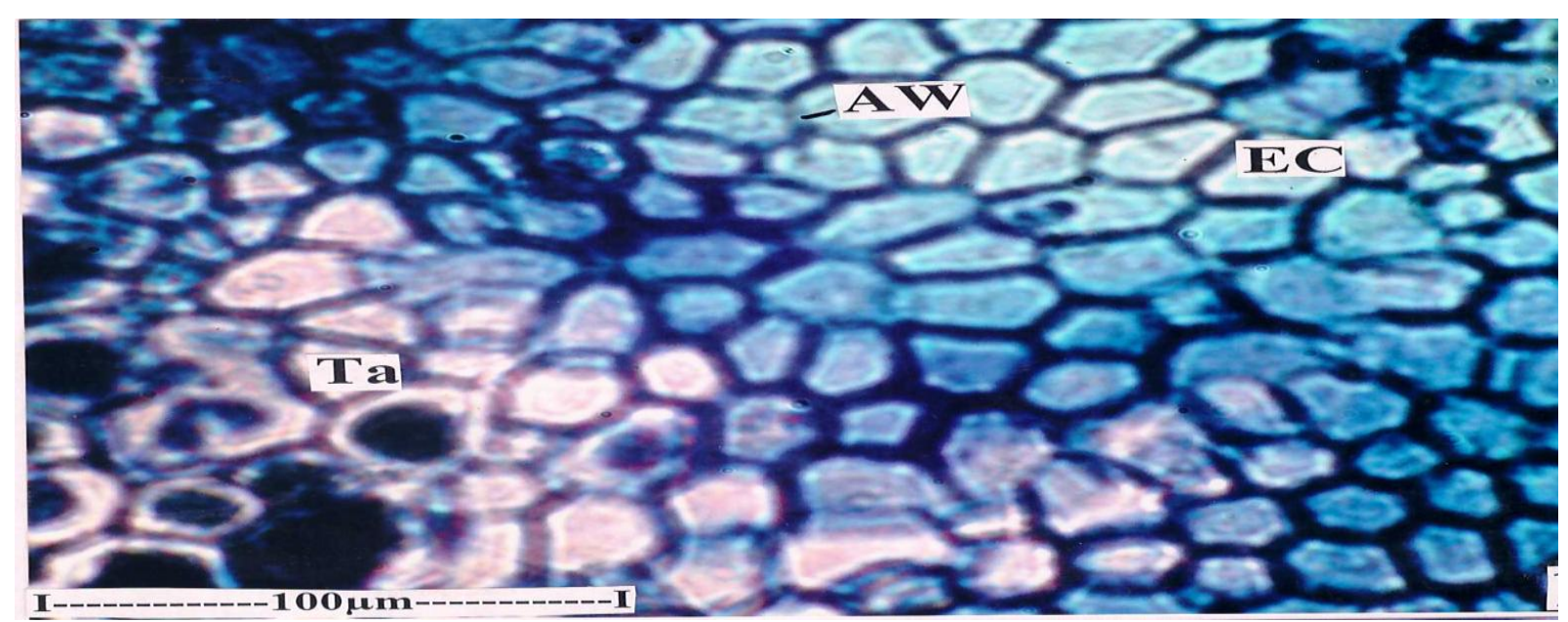

Fig. 4: Ziziphus mauritiana - Adaxial epidermis.

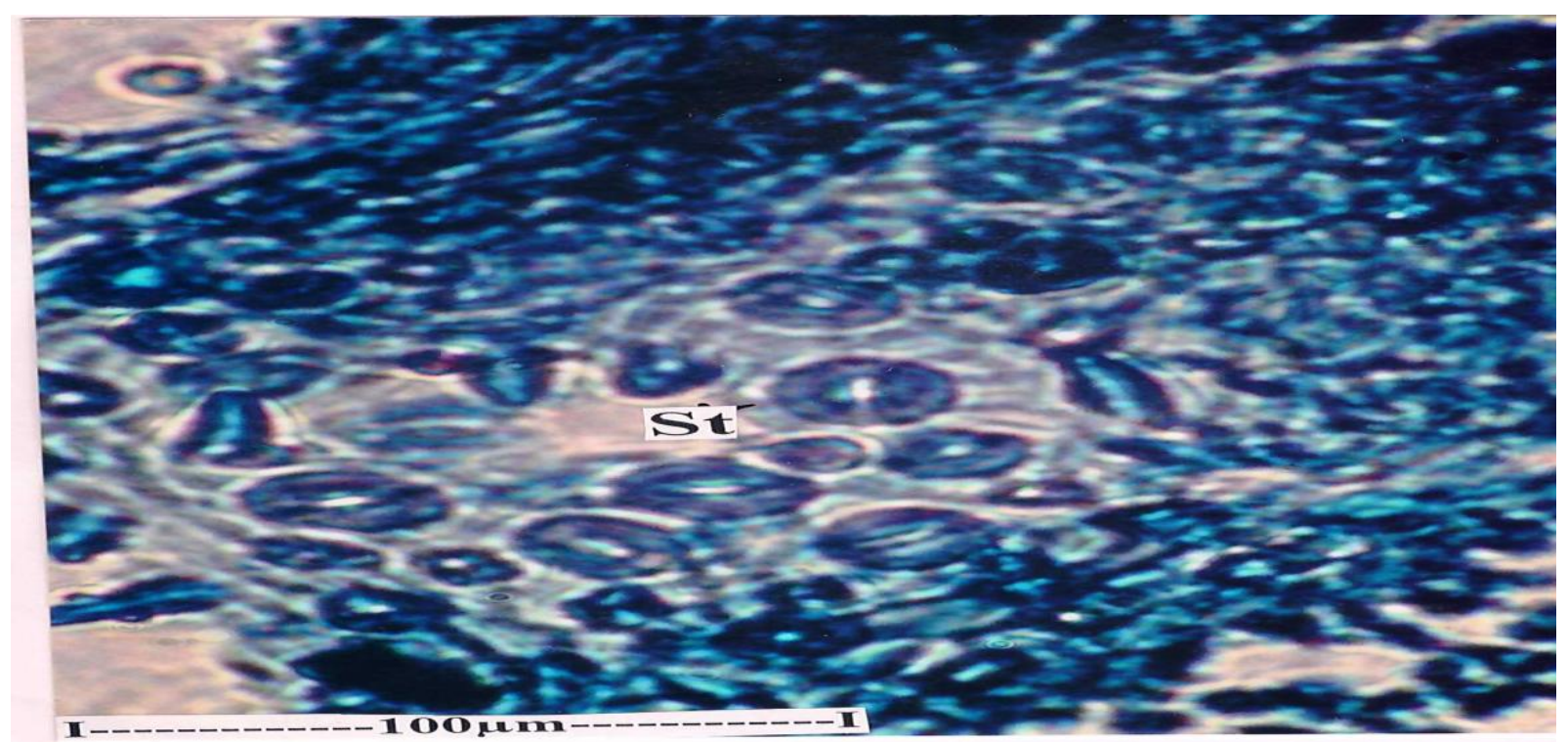

Fig. 5: Ziziphus mauritiana - Abaxial epidermis with stomata.

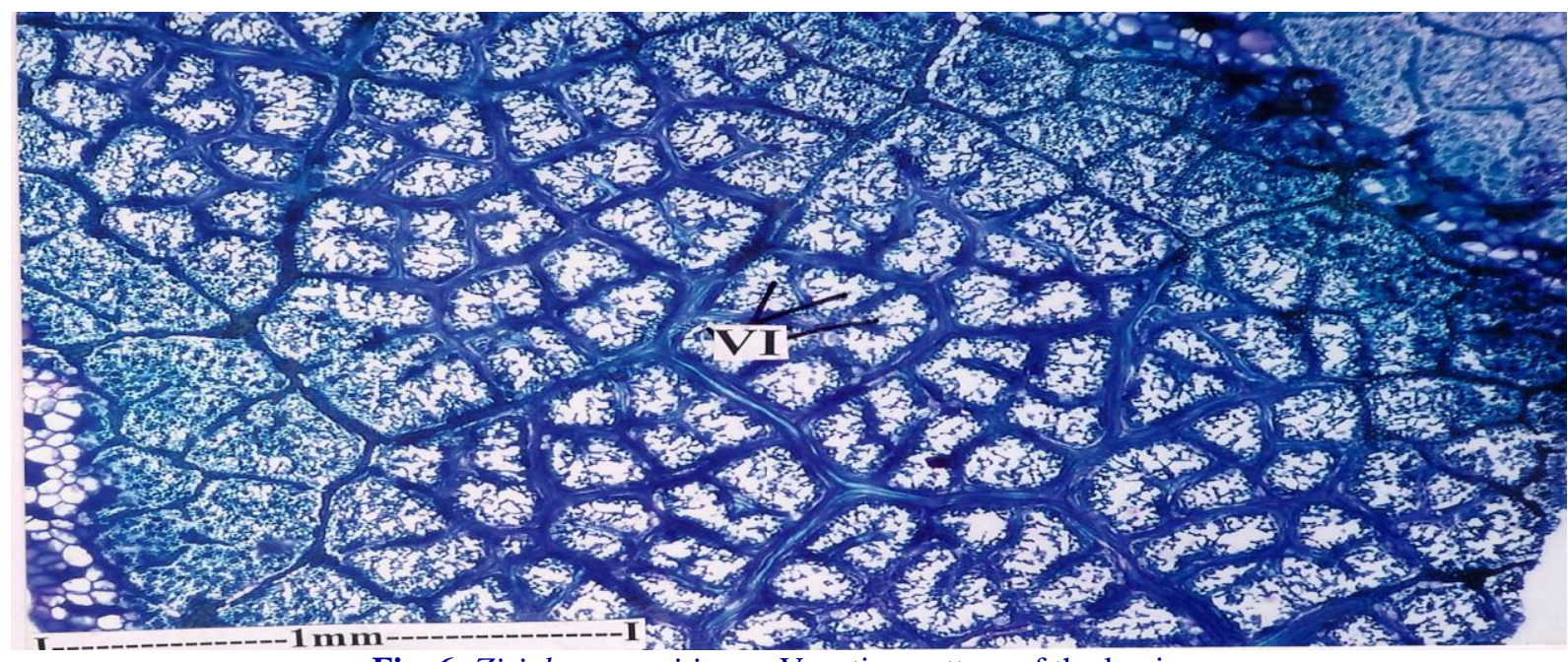

Fig. 6: Ziziphus mauritiana - Venation pattern of the lamina.

(Note: AW- Anticlinal wall, EC - Epidermal cell, ST - Stornata, TA - Tannin, VI - vein islets). 


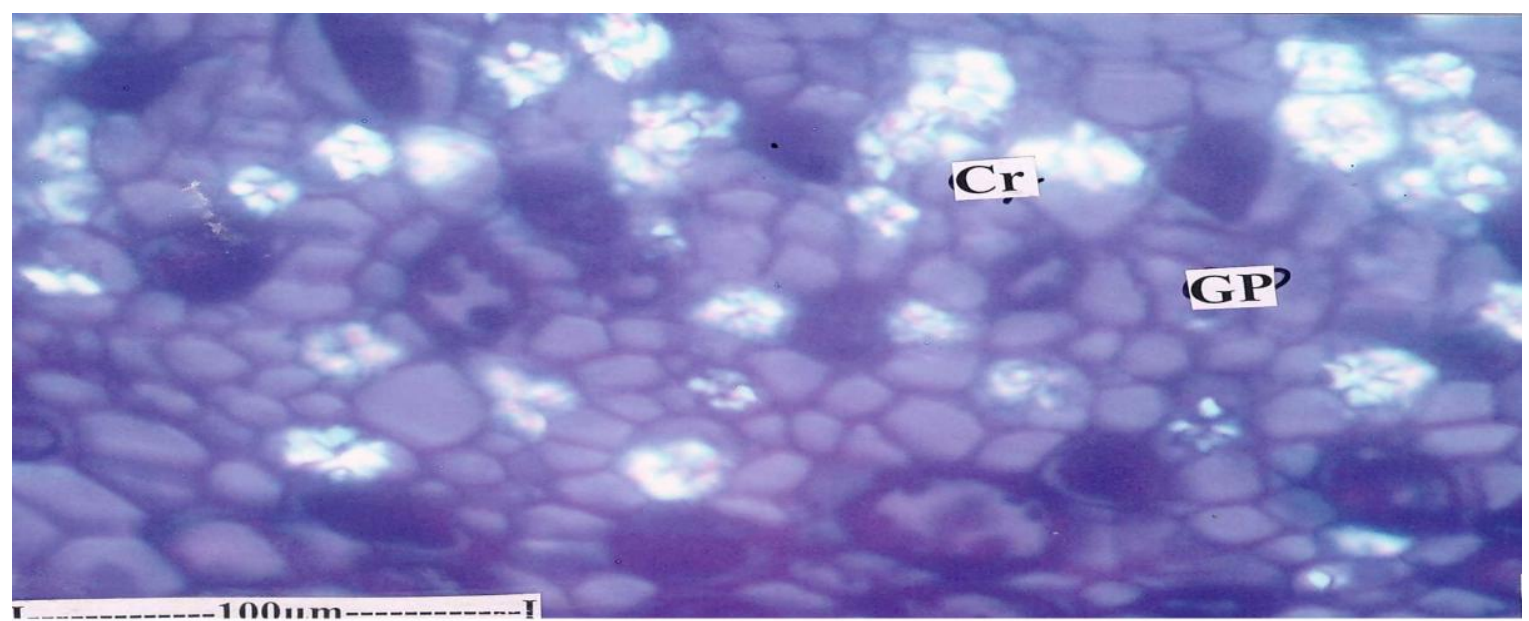

Fig. 7: Ziziphus mauritiana - Surface view of lamina with accumulation of calcium oxalate crystals.

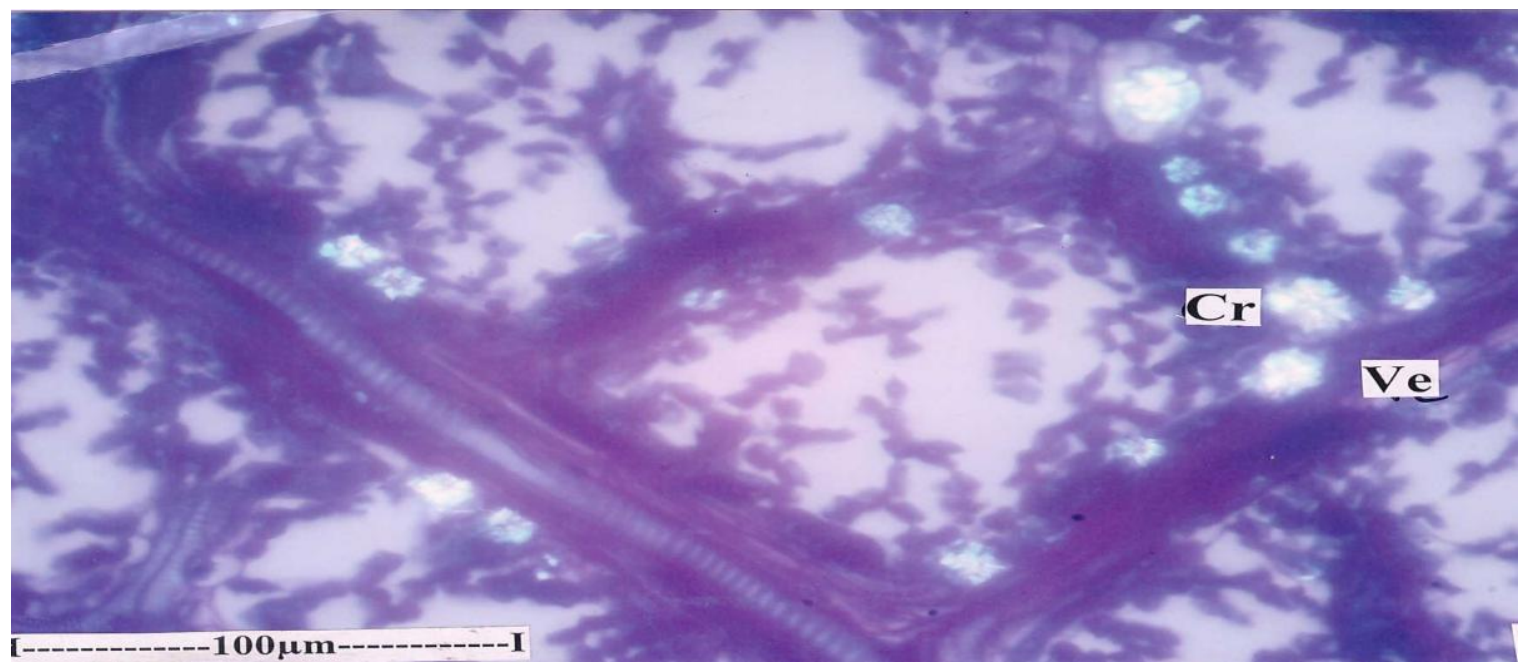

Fig. 8: Ziziphus mauritiana - Lamina showing vertical row of dense crystals.

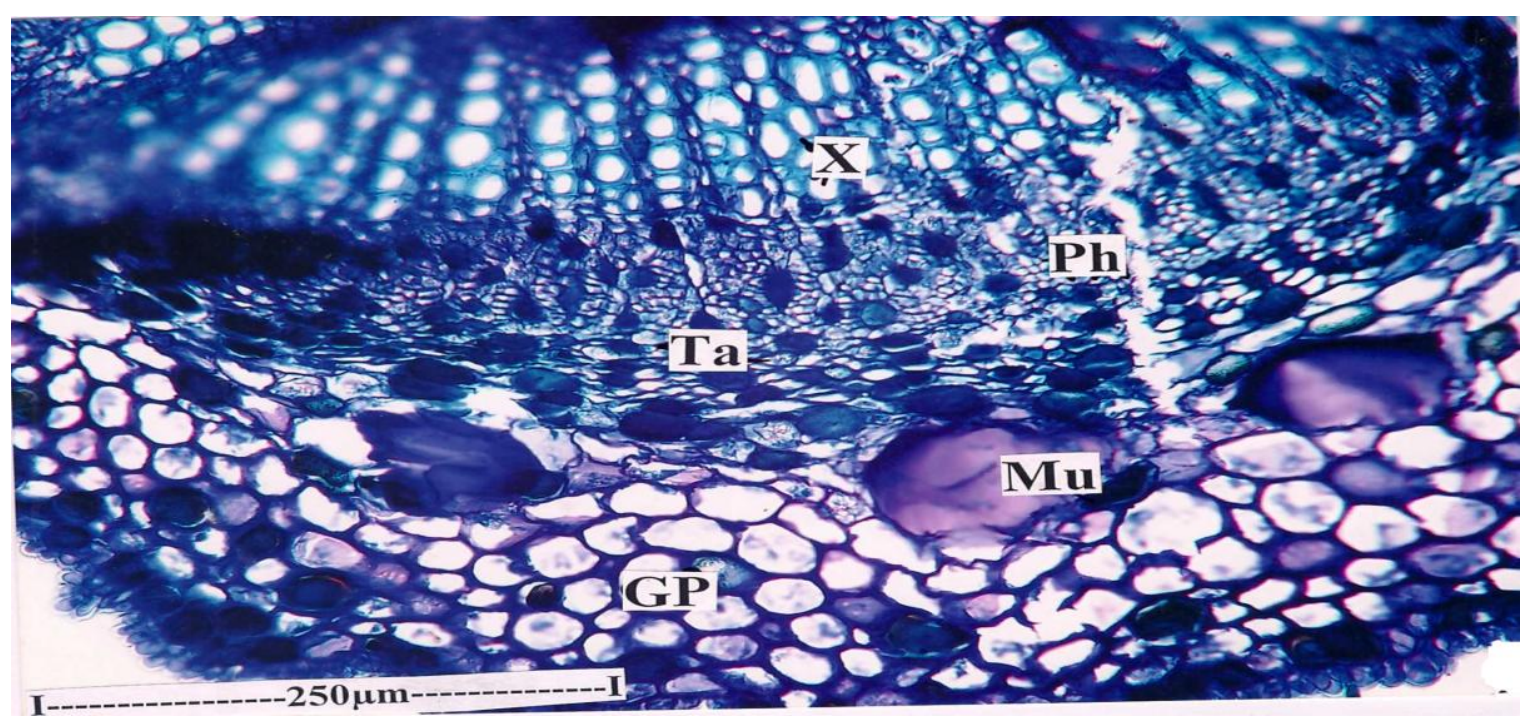

Fig. 9: Ziziphus mauritiana - T.S. of petiole.

(Note: $\mathrm{Cr}$ - Crystals, GP - Ground parenchyma, Ve - Vein, Mu-mucilage, Ph-phloem, TA - Tannin, X-Xylem) 


\section{Lamina}

The lamina is smooth and even on the adaxial side with $200 \mu \mathrm{m}$ thick and the abaxial side consists of thick and large ridges alternating with deep furrows. The abaxial epidermis consists of large vertically oblong thick walled cells with prominent cuticle. The adaxial epidermis is thin and the cells are small and thin walled. The mesophyll tissue consists of adaxial band of 1 or 2 layers of vertically elongated cylindrical palisade cells and abaxial region with small spherical or lobed less compact spongy parenchyma cells. Tannin is found in some of the palisade cells, epidermal cells and bundle sheath cells (Fig. 3).

\section{Epidermal cells and stomata}

The adaxial epidermal layer consists of small, polygonal, thick walled, straight anticlinal walls (Fig. 4). Some of the cells contain dense deposition of tannin. The tannin containing cells are surrounded by rosette of radically elongated cells. The adaxial epidermis is apostomatic. In surface view of the abaxial epidermis, densely distributed stomata are seen. The epidermal cells are small, angular with thick, straight anticlinal walls. The stomata are surrounded by 6 to 7 rectangular subsidiary cells. The guard cells are circular measuring $20 \times 20 \mu \mathrm{m}$ in size. The stomatal pore is prominent and vertically elliptical (Fig. 5).

\section{Venation pattern}

The venation is densely reticulate and the vein lets are thick and straight. They form narrow, polygonal vein islets with thick and straight borders. The vein terminations are seen only in certain vein islets and it is short, thick and straight (Fig. 6).

\section{Crystal distribution}

Calcium oxalate crystals are abundant in the leaf. In the lamina, the crystals are diffusely distributed in dense masses (Fig. 7). Druses are seen in the ground parenchyma cells in the midrib region. The crystals are dense and crowded and are $20 \mu \mathrm{m}$ in diameter (Fig. 8).

\section{Petiole}

The petiole is circular in sectional view and it consists of wavy epidermal layer which includes thick walled, papillate epidermal cells which possess dense tannin content. The ground tissue has thin walled, compactly arranged parenchyma cells. Some of the cells are dilated into mucilage containing idioblast. Tannin is also found in the ground parenchyma cells (Fig. 9).

Similar to other Ziziphus, Z. mauritiana has been reported to contain chemical components such as peptide, cyclopeptide, alkaloids, flavonoids, sterols, tannin, betulinic acid and saponin that present a wide profile of putative therapeutic applications (Shahat et al., 2011).

The vascular bundle is almost circular with wide gap on the adaxial side. The xylem includes several compact radial lines of xylem elements and they are angular and thick walled. Phloem occurs all along the outer boundary of the xylem cylinder. Phloem includes dense and compact sieve elements and dense parenchyma cells having tannin content. Similar results have been observed in Z. mauritiana that showed the presence of saponins, flavonoids, alkaloids, triterpenoids, tannins and phenolic compounds. The leaves possess immmunostimulatory, cardiovascular properties apart from anti-inflammatory, anti-ulcer, wound healing and anti-diabetic activity (Sharma and Gaur, 2013).

\section{Conclusion}

The results presented in this study allowed the identification of leaf characteristics. As there is paucity of information on detailed anatomical features of leaves of $Z$. mauritiana, the present work has been undertaken to provide information with respect to their identification and chemical constitutents. This may be useful for pharmacological studies and standardization of herbal drugs of folk medicinal practice. Hence the present study will also be helpful for further anatomical studies of plants of Rhamnaceae family.

\section{Conflict of interest statement}

Authors declare that they have no conflict of interest.

\section{References}

Chowdary, N.B., Padashetty, N.S., 2000. In vitro screening of antibacterial activity of leaves of Ber. Curr. Res. 29, 78-79.

Clifford, S.C., Arndt, S.K., Popp, M., Jones, H.G., 2002. Mucilages and Polysaccharides in Ziziphus species 
(Rhamnaceae): localization, composition and physiological roles during drought stress. J. Exp. Bot. 53(366), 131-138.

Dahiru, D., Obidoa, O., 2007. Pretreatment of albino rats with aqueous leaf extract of Ziziphus mauritiana protects against alcohol induced liver damage. Trop. J. Pharmaceut. Res. 6, 705-710.

Esau, K., 1964. Plant Anatomy. J. Wiley \& Sons, New York. $767 \mathrm{p}$.

Ganachari, M.S., Shiv, K., 2004. Effect of Ziziphus jujube leaf extract on body weight, food intake and serum lipid levels in sucrose-induced obese rats. Ind. J. Pharmaceut. Sci. 66(3), 363-365.

Hocking, D., 1993. Trees for Drylands. NewDelhi, India. Oxford \& IBH Publishing Co., New Delhi.

Johansen, D.A., 1940. Plant Microtechnique. Mcgraw Hill Book Co., New York. 222p.

Michel, A., 2002. Tree, Shrub and Liana of West African Zones. Margraf Publishers GMBH, Paris. 440p.

Morton, J., 1987. Indian jujube. In: Fruits of Warm Climates (Eds.: Mortan, J.F., Miami, F. L.). Center for New Crops \& Plant Products, Purdue University, Lafayette, Ind, USA. pp.272-275.

O’Brien, T.P., Feder, N., McCull, M.E., 1964. Polychromatic staining of plant cell walls by toluidine blue. Protoplast. 59, 364-373.

Shahat, A.A., Ibrahim, A.Y., Hendawy, S.F., Omer, E.A., Hammouda, F.M., Abdul Rahman, F.H., Saleh, M.A., 2011. Chemical composition, antimicrobial and antioxidant activity of essential oil from organically cultivated fennel cultivars. Molecules. 16(2), 1366-1377.

Sharma, G.N., Gaur, A., 2013. Ziziphus mauritiana Lam.-An overview. Indo Amer. J. Pharm Res. 3(6), 4560-4566.

Sivasankari, M.P., Sankaravadivoo, A., 2015. Studies on antimicrobial activity on Ziziphus mauritiana Lam. Int. J. Ayurv. Pharma Res. 3(7), 52-55.

Townsend, C.C., Guest, E., 1980. Flora of Iraq. Baghdad. Vol.4, Part One. pp.432-437.

Wetmore, R., Wardlaw, C.W., 1951. Experimental morphogenesis in vascular plants. Ann. Rev. Plant Physiol. 2, 269-292.

\section{How to cite this article:}

Sivasankari, M. P., Sankaravadivoo, A., 2017. Leaf anatomical studies of Ziziphus mauritiana Lam. Int. J. Curr. Res. Biosci. Plant Biol. 4(8), 73-79. doi: https://doi.org/10.20546/ijcrbp.2017.408.010 